\title{
A Pilot Study of Current Trends in Information and Communication Technology (ICT) Education within the Tertiary Sector
}

\author{
Mehdi Asgarkhani \\ CPIT \\ E-Mail: AsgarkhaniM@CPIT.ac.nz \\ Jun Wan \\ CPIT \\ E-Mail: WanJ@CPIT.ac.nz
}

\begin{abstract}
The purpose of this paper is to elaborate on the effectiveness of information systems and information technology education for developing work-ready graduates. It compares Information and Communication Technology (ICT) skills that students acquire throughout their course of studies with skills identified by the ICT industry as being crucial for the ICT job sector. The critical skills as seen by ICT workplaces were identified by investigating a sample of 205 randomly selected ICT roles and their associated skill requirements. Our first impression of what students learn and their views of crucial ICT skills were established through a case study of a focus group of graduating ICT students. The outcome of the two studies are compared and reflected upon in this paper.
\end{abstract}

Keywords: Information and Communication Technology (ICT), Information Systems and Technology, ICT Education, ICT Education Effectiveness, Crucial ICT Skills

\section{INTRODUCTION}

Today, rapid development of Information and Communication Technologies (ICTs) increasingly creates opportunities for developing innovative ICT and web based information management solutions - which in turn significantly benefit organizations (Asgarkhani, 2005; OECD Information technology Outlook, 2006). As a 
result, within the last decade, investment on ICTs in most organizations has become the largest component of capital expenditure. In the United States alone, the capital expenditure on ICT equipment and infrastructure in 2005 estimated to have reached \$1.8 trillion (Lauden \& Lauden, 2006 and Lauden \& Lauden, 2005). The percentage of ICT capital expenditure expanded from 19\% (of the total business investments) in 1980 to 35\% in 2003 (source: US Department of Commerce, Bureau of Economic Analysis, National Income and Product Accounts). What's more, ICTs have also contributed significantly towards GDP growth within most countries. For instance, a recent research (European Commission Enterprise and Industry Directorate-General, Brussels, 2006) shows that from 1995 to 2004 the GDP growth as a consequence of ICTs was 3.4\% in USA, $2.9 \%$ in the UK and 2.1\% in European Union (EU15).

Large investment components are often associated with significant risks. The potential pitfalls of large risky capital investments on ICTs and technology solutions have led to an ever growing concern for ensuring the best return for adopted ICT solutions (Asgarkhani, 2005; Lauden \& Lauden, 2006; Lauden \& Lauden, 2005; Harper, 2003 and Robson, 1997). More specifically, as capital investment on ICT within corporations continues to grow, there is an expectation that ICT investments are optimized. It has become critical to not only maximize the benefits that are offered (through the application of ICTs and other technology solutions) but must also avoid the many pitfalls and risks (economical, social and cultural) that are associated with rapid technological change. To protect organization's investment on ICT solutions, organizations have been increasingly relying on skilled ICT staff in order to maximize the benefits of ICTs to various units within organization. We have witnessed a growing demand for knowledgeable ICT workers (Zyngier, 2003; The ICT skills foresighting working group, 2006; Hsieh \& Chen, 2003 and European Commission Enterprise and Industry Directorate-General, 2006).

A recent review of trends in needs for ICT workers (and specific skill needs) demonstrates that in 2003, ICT specialists accounted for up to 5\% of total employment in all countries. What's more, ICT specialists and ICT-using occupations combined generally accounted for 20-30\% of total employment (OECD Information Technology Outlook 2006). Research in U.S., EU15, Canada and Australia also shows a change in the share of ICT-skilled employment in the workplace. There has been an average increase of $0.5 \%$ (on an annual basis) in number of ICT specialists in organizations from 1995 to 2004 (DSTI/ICCP/IE (2004)10/FINAL Unclassified, 2005).

In recent years there has been much debate so as to what is being considered as valuable and/or effective ICT skill(s). Additionally, it is widely argued that a 
successful ICT worker needs to not only be highly skilled but also be able to respond to the ever changing knowledge of ICTs (Gregorian, 2002; Asgarkhani, 2004; Asgarkhani, 2003; The ICT skills foresighting working group, 2006; Hasanali, 2002 and Gregorian, 2002). In other words, the knowledge and skills we acquire today are in danger of becoming obsolete rapidly. Therefore, new approaches to learning ICTs have continuously replaced traditional learning approaches. It is therefore crucial that the ICT skills offered by tertiary sector are not only offered/delivered in an effective manner but also are closely aligned with critical ICT skill shortages (as identified by the industry). That is to say, a broader range and/or greater depth of skills that can help further learning on an ongoing basis are needs of today's ICT learners.

In early 2006 a project was initiated to investigate key issues that concern effectiveness (developing work-ready graduates) of ICT education within New Zealand. The preliminary results of this study (through the investigation of 205 randomly selected ICT jobs) identified key skills and personal attributes (amongst other parameters) as evident from the ICT sector's employment needs. Furthermore, the project involved a pilot study (case study) of a focus group of 35 graduating students within an ICT tertiary qualification. The study of the focus group aimed at validating research questions, clarifying key issues/trends and fine tuning methodology and/or research questions.

This paper discusses the results of the pilot study (case study) which was mentioned above compared with that of industry's view of crucial ICT skills.

Some of the key issues that are addressed include (but are not limited to):

1. ICT sector's view of critical skills

2. Skills learned by students (in the focus group) as part of their studies towards their ICT qualification

3. Students' perception of critical ICT skills that can secure success within workplace

4. A comparison of skills learned by students and industry's view of crucial skills.

5. A comparison of critical skills from both students' view and the industry's view.

The results discussed in this paper are based on analysis of the data collected from various sources - including:

1. A review of some of previously published investigations discussing key issues about developments, trends and ICT sector's needs for information age workers (Kozma, 2005; Pye \& Marchmont Observatory, 2000; Hasanali, 2002; Gallagher \& Newman, 2002; Evans, 2003 and Dechawatanapaisal, 2005). 
2. Randomly selected job/role descriptions within the ICT job market.

3. Valuation of ICT students' view of critical ICT skills for workplace and the skills they learn throughout studies - based on analysis of the results concerning an online survey of a focus group of ICT students. More specifically, a focus group of 56 Bachelor of ICT and Graduate Diploma in ICT students was formed. These students were asked to participate in an online survey. Only 35 students responded.

\section{CRITICAL ICT SKILLS: ICT SECTOR VIEW VERSUS STUDENTS’ EXPECTAIONS}

In this section, we will discuss the preliminary results from a previous study (as mentioned earlier in the introduction) that was carried out as the cooperative industry project by a graduate diploma in ICT student.

Students were firstly asked to select their preferred ICT job categories (of various roles). We hoped to establish an understanding of what roles were being preferred by this particular group of students. We also intended to compare their views with what we established as being most required roles as seen by the industry.

Table 1 demonstrates to what extent classified jobs (roles) rated as being preferred by students agree or disagree with ICT job market of the most needed roles. We looked at types of roles (jobs) that were included in our randomly selected sample. It appeared that the highest percentage of jobs in the sample related to the category of systems development (40.98\%). This was followed by operations (10.73\%) and infrastructure roles $(8.78 \%)$. The overall ratings (percentage of roles within the sample) are outlined in the first column of Table 1 . Next, we tried to relate the findings from the industry to students' views (the second column of Table 1) as determined by conducting the case study of the focus group of students - as mentioned earlier.

It was somewhat surprising to see that students rated the job category(ies) of their interest to include project management (48.6\%), system development (35.1\%). It was expected that system development roles are of more interest. This could be a result of the fact that at the time of the survey, emphasis (by the tertiary institution concerned) was placed on students' ability to be prepared for completing their industry based project (a requirement of qualifications they were studying towards). It is also interesting to notice that information management and user support (both 32.4\%) were seen as highly desirable roles by this focus group of students.

Comparing the two columns shows that students' interest is consistent with industry needs in three out of the top five roles. More specifically, our sample 
identifies system development, operations, infrastructure, project management and advice and consultancy to be the top five required roles (industry view). On the other hand, students identified project management, system development, information management and user support followed by advice and consultancy as their top five preferred roles. The agreement between students' interest in roles and ICT sector's requirements seems to be weaker when we consider the rest of the job categories that are outlined in Table 1.

Table 1 Classified jobs rated in ICT job market and by students

\begin{tabular}{|l|l|}
\hline Job categories observed by the ICT job market & Job categories (roles) preferred by students \\
\hline System Development (40.98\%) & Project Management (48.6\%) \\
\hline Operations (10.73\%) & System Development (35.1\%) \\
\hline Infrastructure (8.78\%) & Information Management (32.4\%) \\
\hline Project Management (5.85\%) & User Support (32.4\%) \\
\hline Advice and Consultancy (5.36\%) & Advice and Consultancy (27\%) \\
\hline $\begin{array}{l}\text { Sales, Marketing \& Business Management } \\
(4.88 \%)\end{array}$ & Operations (27\%) \\
\hline User Support (4.39\%) & $\begin{array}{l}\text { Resource/General ICT management } \\
(24.3 \%)\end{array}$ \\
\hline Education \& Training (3.41\%) & Strategy \& planning (24.3\%) \\
\hline Quality Management (2.93\%) & Infrastructure (21.6\%) \\
\hline Resource/General ICT Management (2.93\%) & Education and Training (18.9\%) \\
\hline Strategy \& Planning (2.44\%) & Installation and Integration (18.9\%) \\
\hline Information Management (1.95\%) & Quality management (18.9\%) \\
\hline Other Classifications (1.95\%) & Technical Strategic (18.9\%) \\
\hline Technical Strategic (1.95\%) & $\begin{array}{l}\text { Sales, Marketing \& Business Management } \\
(13.5 \%)\end{array}$ \\
\hline Human Factors (1.46\%) & Human Factors (8.1\%) \\
\hline Installation and Integration (0\%) & Other classifications (8.1\%) \\
\hline Supply Management (0\%) & Supply Management (5.4\%) \\
\hline
\end{tabular}

Next, we look at skill requirements as outlined by the ICT sector. Figure 1 demonstrates the skills required by the ICT job market determined by evaluating 205 randomly selected ICT related jobs. The results clearly demonstrated that technical skills as related to system development of applications (including knowledge of all developing tools, open source environment and software designing) are seen as being amongst the most required (mentioned more often than other skills as we analysed the 205 roles in the sample) skills (14.24\%). In other words, system or application 
development as a skill was referred to (selected) $14.24 \%$ of the total number of times all skills were mentioned. This is followed by technical skills in networking technologies (11.89\%) and skills related to databases (9.05\%), development methods and hardware \& operating systems (7.37\%). These results indicate that, as expected, technical skills still play a dominating role in ICT industry.

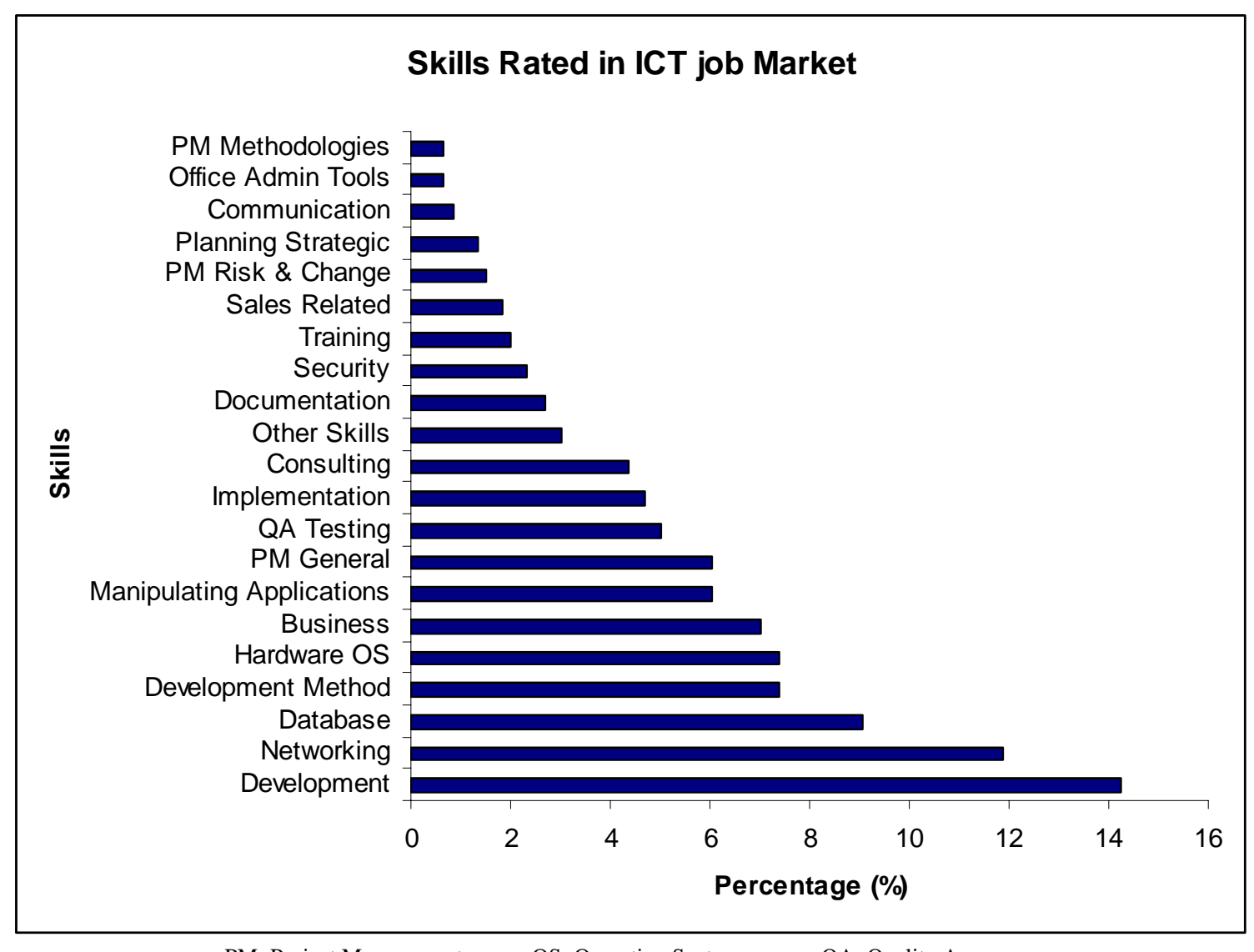

PM: Project Management

OS: Operating System

QA: Quality Assurance

Figure 1 Analysis of Skills Relevant to the 205 ICT Roles Investigated

Students of the focus group were asked (without being concerned with their choice of preferred roles) to nominate in general those ICT skills they would like to learn - in order to be a successful ICT worker. We hoped to compare their responses with what industry viewed as being crucial ICT skills and conduct an analysis of similarities or differences. The comparison could possibly highlight "to what extent students are actually aware of real skill needs within the sector."

We also asked the students to identify the skills they had been learning throughout their course of studies. We hoped to be able to establish an understanding 
of whether or not those skills they were learning had any resemblance (closeness) to what industry actually viewed as being critical (Figure 1).

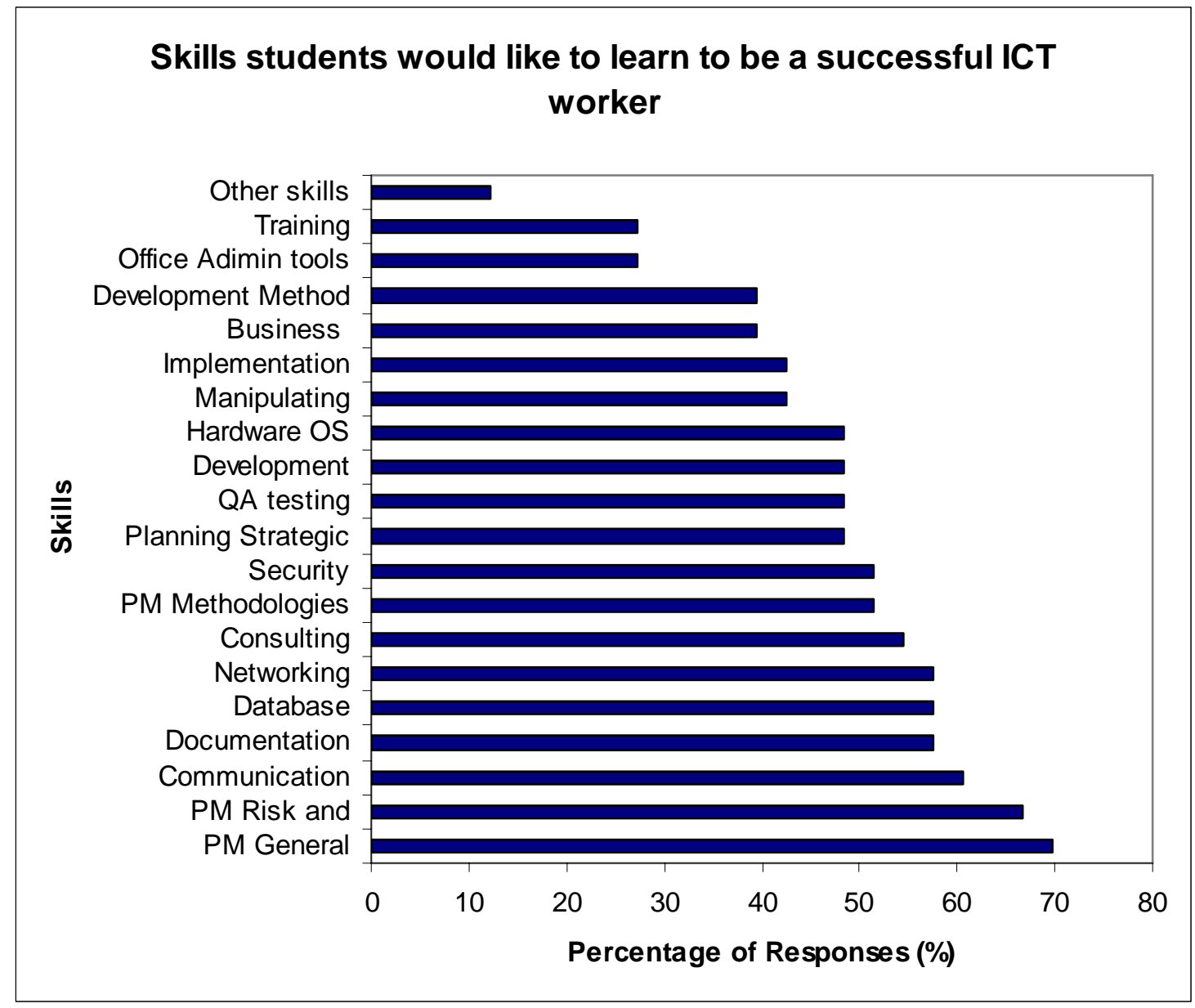

Figure 2 Skills students would like to learn to be a successful ICT worker

Figure 2 illustrates students' view of the ICT skills (in general and not attached to preferred job category) they preferred to learn in order to be a successful ICT worker. As we can see, skills related to project management (general project management skills, risk and change management skills) are rated as the top two desired skills. Following the top two skills, communication skills and documentation skills are also seen as highly desirable. This can be explained in two different ways. It may simply imply that there is a perceived lack of project management skills. Alternatively, it may be interpreted as students viewing these skills as being critical to their future success in workplace. 


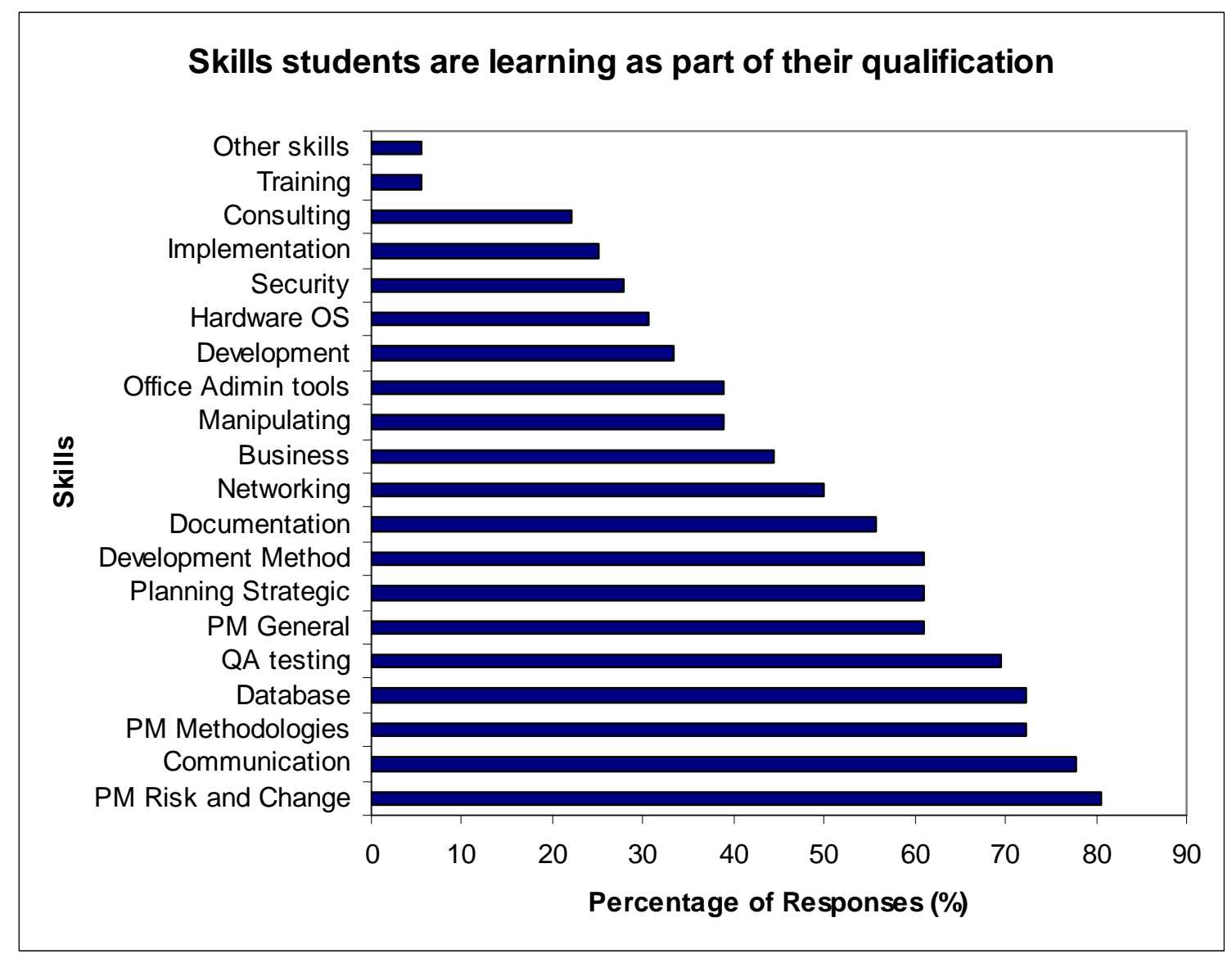

Figure 3 Skills students are learning as part of their qualification

By comparing Figures 1 and 2, we can observe that there are some inconsistencies between what students expect to learn in order to be successful and what industry views as being most valuable skills for workplace. Despite the fact that the industry required technical skills more than other skills, students of this focus group seemed to expect to learn non technical skills (communication skills, documentation skills and project management related skills). Moreover, whereas the skill of development method was rated as being valuable by the industry it was seen as being insignificant by students. This could be interpreted as a sign of lack of students' understanding of the industry's needs. However, these results (students' views) represent one focus group only and cannot be seen as applicable to all cases. Nonetheless, it has to be noted that some consistencies between industry needs (of skills) and students' perception of what they needed to learn were apparent. For instance, both students and the industry rated the skills related to office administration tools as being insignificant. 
Students were also asked to identify the ICT skills they were learning as part of their qualification. The skills identified by students are demonstrated in Figure 3. The top ten skills that were mentioned included: project management (risk and change), communication, project management (methodologies), database systems, QA (quality assurance) \& testing, project management (general), strategic planning, development methods, documentation and networking.

By comparing Figures 2 and 3, we can establish whether or not students are learning the skills they expect to learn. As we can observe, the top three skills in both tables are consistent as they relate to project management and communication skills. Furthermore, the training skills and other skills (such as storage management, workflow management, and digital workflow to name but a few) are seen as being insignificant in both Figures 2 and 3. At the same time, the inconsistencies exist. For instance, consulting skills are rated as the third from bottom in Figure 3 whilst it is placed as the seventh highest skill in Figure 2. What's more, students do not see learning development methods as being a success factor at workplace (Figure 2) whilst it is one of the top 10 skills they are indeed learning (Figure 3).

Next, we compare industry view of required skills (Figure 1) with that of what students are learning (Figure 3). By comparing Figures 1 and 3, once again there appears to be some mismatch between the skills learned by students and industry's view of crucial skills for workplace. For instance, students are learning project management (risk and change), communications, project management (methodologies), databases, QA (quality assurance) \& testing and project management (general). The top six skills of industry's view are: system development, networking, databases, development methods, hardware \& operating systems and business skills. As you can observe, only one out of top six skills from Figure 3 matches with what is demonstrated in Figure 1. The inconsistency may raise the question of whether or not tertiary sector is in tune with the industry. However, we cannot yet apply what we have learned from this preliminary study to all cases across the board - reasons being:

1. There is a need for studying more focus groups so as to more accurately identify issues of concern (if any).

2. It has been widely debated that a broader range and/or greater depth of skills that can help further learning on an ongoing basis is a need for today's ICT learners (as mentioned in introduction). The skills such as project management, 
documentation, communication could potentially facilitate more effective pathways to future learnings within a knowledge society.

Once again, we would like to emphasize that these results are the preliminary results of a pilot case study only. That is to say, even though some interesting (and debateable) trends have been brought to our attention, we cannot generalize the outcome until further studies (study of more focus groups) are carried out. However, it has been encouraging to observe that there is awareness (to some extent) in students of some of required skills by the industry. Furthermore, it is noticed that the students in this particular focus group are willing to broaden the range and depth of their learnings beyond traditional technical ICT skills - that are often the focus of training and educational institutions.

\section{SUMMARY AND CONCLUSIONS}

In recent years there has been much debate over what ICT skills are being seen as valuable within the workplace. Both ICT specialists and educators seem to agree that a successful ICT worker needs to not only be highly skilled but also be able to respond to the increasing need for learning on an ongoing basis. In other words, the key success factor is not merely learning ICT skills but also being able to adopt new technologies and learn new skills on an ongoing basis.

The thrust of discussions in this paper is to highlight the effectiveness of ICT education - with a focus on tertiary sector. More specifically, it is generally about the ways in which tertiary ICT educators attempt to develop students' skills and prepare them for workplace.

We compared ICT skills that students acquire with what industry views as being crucial skills for workplace - as identified through the analysis of 205 randomly selected ICT roles and their associated skill requirements. A preliminary understanding of what students learn and their views of winning ICT skills were established through a case study of a focus group of 35 graduating ICT students.

Table 2 compares (demonstrates agreements and disagreements) skill needs as rated by the ICT job sector with that of students' views. As we can observe, one of the skills (sales related) in column 1 (ICT sector views of needed skills) is not included in neither column 2 (skills students are learning as part of their qualification) nor in column 3 (skills students would like to learn to be a successful ICT worker). This is a esult of not having this option (sales related skills) made available in the questions designed for online survey of students of the focus group. 
Table 2 Skills rated in ICT job market and by students

\begin{tabular}{|l|l|l|}
\hline $\begin{array}{l}\text { Skills rated by ICT job } \\
\text { sector (Industry) }\end{array}$ & $\begin{array}{l}\text { Skills students are learning } \\
\text { as part of their } \\
\text { qualification }\end{array}$ & $\begin{array}{l}\text { Skills students would like } \\
\text { to learn to be a successful } \\
\text { ICT worker }\end{array}$ \\
\hline System Development (14.24\%) & PM Risk and Change (80.6\%) & PM General (69.7\%) \\
\hline Networking (11.89\%) & Communication (77.8\%) & PM Risk and Change (66.7\%) \\
\hline Database (9.05\%) & PM Methodologies (72.2\%) & Communication (60.6\%) \\
\hline Development Method (7.37\%) & Database (72.2\%) & Documentation (57.6\%) \\
\hline Hardware OS (7.37\%) & QA testing (69.4\%) & Database (57.6\%) \\
\hline Business (7.04\%) & PM General (61.1\%) & Networking (57.6\%) \\
\hline $\begin{array}{l}\text { Manipulating Applications } \\
\text { (6.03\%) }\end{array}$ & Planning Strategic (61.1\%) & Consulting (54.5\%) \\
\hline PM General (6.03\%) & Development Method (61.1\%) & PM Methodologies (51.5\%) \\
\hline QA Testing (5.03\%) & Documentation (55.6\%) & Security (51.5\%) \\
\hline Implementation (4.69\%) & Networking (50\%) & Planning Strategic (48.5\%) \\
\hline Consulting (4.36\%) & Business (44.4\%) & QA testing (48.5\%) \\
\hline Other Skills (3.02\%) & $\begin{array}{l}\text { Manipulating Applications } \\
\text { (38.9\%) }\end{array}$ & System Development (48.5\%) \\
\hline Documentation (2.68\%) & Office Admin tools (38.9\%) & Hardware OS (48.5\%) \\
\hline Security (2.35\%) & System Development (33.3\%) & $\begin{array}{l}\text { Manipulating Applications } \\
\text { (42.4\%) }\end{array}$ \\
\hline Training (2.01\%) & Hardware OS (30.6\%) & Implementation (42.4\%) \\
\hline Sales Related (1.84\%) & Security (27.8\%) & Business (39.4\%) \\
\hline PM Risk \& Change (1.51\%) & Implementation (25\%) & Development Method (39.4\%) \\
\hline Planning Strategic (1.34\%) & Consulting (22.2\%) & Office Admin tools (27.3\%) \\
\hline Communication (0.84\%) & Training (5.6\%) & Training (27.3\%) \\
\hline Office Admin Tools (0.67\%) & Other skills (5.6\%) & Other skills (12.1\%) \\
\hline PM Methodologies (0.67\%) & & \\
\hline
\end{tabular}

We observed that three out of the top five role types as needed by the ICT sector matched what students rated as their top five preferred ICT jobs/roles.

Students rated project management skills (general project management skills, risk and change management skills) and communication as their top three desired skills for success in the job market. However, the top three skills (mentioned most often in job descriptions we analysed) were system development, networking and databases.

The skills students were learning as part of their qualifications seemed to be consistent with what they desired to learn for being work-ready. On the other hand, the top three skills they were taught as part of their qualifications (project 
management change and risk, communication and project management methodologies) did not agree with most frequently mentioned skills by the ICT sector (based on the sample of job descriptions that were investigated).

To summarize, the skills that students expect to learn seem to be fairly consistent with what they are actually learning - even though there are some minor inconsistencies. However, there are major inconsistencies in what they want to learn compared with the perceived job market needs. What's more, the skills this particular group of students were learning also appeared to be largely inconsistent with industry needs.

As we have noted on a number of occasions, this study highlights some notable trends for consideration. However, we also emphasized that this is the outcome of a pilot study. That is to say, we cannot generalize these results to be applicable to all institutions and all ICT students across the board.

In conclusion we would like to recommend that:

1. Further studies of additional focus groups (different groups of students from different tertiary institutions) to be carried out to further validate some of the results that we have discussed in this paper.

2. A further breakdown of job and skill categories to be considered (and further analysis to be carried out) so as to be able to more accurately assess the required skill categories within the ICT sector compared with what develops within the tertiary sector.

\section{REFERENCES}

Asgarkhani, M. (2005). Digital Government and its Effectiveness in Public Management reform: A Local Government Perspective. Journal of Public Management Review, 7 (3), 465-488.

Asgarkhani, M. (2004). The Need for a Strategic Foundation for Digital Learning and Knowledge Management Solutions. Electronic Journal of e-Learning, 2(2), 3142.

Asgarkhani, M. (2003). Web-Assisted Teaching and Learning: A Study of Current Trends and Issues for Future Consideration. The New Zealand Journal of Applied Computing and Information Technology, 7(1), 7-10.

Dechawatanapaisal, D. (2005). HRM as Enablers of Learning Work Behaviour: Perspectives from Thai ICT Professionals. Retrieved December 11, 2006, from http://rphrm.curtin.edu.au/2005/issue1/enablers.html 
European Commission Enterprise and Industry Directorate-General, Brussels. (30 June 2006). Effects of ICT Capital on Economic Growth. Retrieved February 21, 2007, from http://ec.europa.eu/enterprise/ict/policy/doc/ict-cap-eff.pdf

Evans., N. (2003). Informing Clients in Education about Instructional Offerings and Careers in the ICT Industry. Retrieved February 9, 2007, from http://proceedings.informingscience.org/IS2003Proceedings/docs/073Evans.pdf

Gallagher, S., and Newman, A. (2002). Critical Success Factors to Growing Fully Online Distance Learning Programs. Retrieved January 21, 2007, from http://www.eduventures.com/pdf/distance.pdf

Gregorian, V. (2002). Succeeding in the $21^{\text {st }}$ Century - What Higher Education must do to address the gap in Information and Communication Technology Proficiencies. Retrieved March 11, 2007, from http://www.calstate.edu/ls/ ICTwhitepaperfinal.pdf

Harper, J. (2003). Information and Communications Technology Industry - Northern Territory. Retrieved March 21, 2007, from http://www.nt.gov.au/dcis/ it/docs/industry_development/final_report_ict_survey_2002.pdf

Hasanali, F. (2002). Critical Success Factors for Knowledge Management Systems. Retrieved February 11, 2007, from http://www.kmadvantage.com/docs/ km_articles/Critical_Success_Factors_of_KM.pdf

Hsieh, C., and Chen, K. (2003). Critical Success Factors for Implementing a Corporate Knowledge Management System. Retrieved April 27, 2007, from http://www.sbaer.uca.edu/research/2003/swdsi/Papers/050.pdf

Pye, J. and the Marchmont Observatory. (2000). Promoting workplace learning with ICT: Modes and Models for organizational Change. Retrieved January 12, 2007, from http://www.leeds.ac.uk/educol/documents/00001611.htm

Kozma, Robert B. (2005). ICT, Education Reform and Economic Growth. Retrieved December 26, 2006, from download.intel.com/education/wsis/ICT_ Education_Reform_Economic_Growth.pdf

Lauden, K.C., and Lauden, J.P. (2006). Management Information Systems, $9^{\text {th }}$ Edition, New Jersey, USA, Person Prentice Hall.

Lauden, K.C., and Lauden, J.P. (2005). Essentials of Management Information Systems, 6th Edition, New Jersey, USA, Person Prentice Hall.

OECD Information Technology Outlook. (2006). Information Technology Outlook 2006 Highlights. Retrieved February 9, 2007, from http://www.oecd.org/ dataoecd/27/59/37487604.pdf 
OECD. DSTI/ICCP/IE - 10/FINAL - Directorate for Science, Technology and Industry. Committee for Information, Computer and Communication Policy. (2005). New Perspectives on ICT Skills and Employment. Retrieved January 27, 2007, from http://www.oecd.org/dataoecd/26/35/34769393.pdf

The ICT skills foresighting working group. (2006). Building Australian ICT skills. Retrieved December 19, 2006, from http://www.escc.org/docs/ Building_Australian_ICTskills.pdf

Robson, W. (1997). Strategic Management \& Information Systems $-2^{\text {nd }}$ Edition, New Jersey, USA, Prentice Hall.

Zyngier, S. (2003). The Role of Technology in Knowledge Management Strategies in Australia: Recent Trends. Journal of Information \& Knowledge Management, 2(2), 165-178. 